\title{
PRODUKTIVITAS KERJA DAN TINGKAT PARTISIPASI KERJA (TPK) WANITA PENGERAJIN TENUNAN TRADISIONAL DI DESA JINENG DALEM KABUPATEN BULELENG BALI
}

\author{
Oleh \\ I Gede Sudirtha dan Putu Agus Mayuni \\ Jurusan Pendidikan Kesejahteraan Keluarga, FTK, UNDIKSHA
}

\begin{abstract}
ABSTRAK
Penelitian ini bertujuan untuk mengetahui dan mengkaji tentang : (1) produktivitas kerja para wanita pengerajin tenunan tradisional di Desa Jineng Dalem Kabupaten Buleleng Bali, (2) tingkat partisipasi kerja (TPK) para wanita pengerajin tenunan traditional di Desa Jineng Dalem Kabupaten Buleleng Bali, (3) kontribusi terhadap perekonomian keluarga oleh para wanita pengerajin tenunan tradisional di Desa Jineng Dalem Kabupaten Buleleng Bali, (4) sistem regenerasi yang dilakukan dalam meneruskan usaha tenunan tradisional di Desa Jineng Dalem Kabupaten Buleleng Bali. Subek dari penelitian ini adalah wanita pengerajin tenun tradisional di Desa Jineng Dalem Kecamatan Buleleng Kabupaten Buleleng Bali. Responden dalam penelitian ini adalah : para wanita yang bekerja sebagai pengerajin tenun (tidak termasuk yang sedang sekolah). Dengan demikian keseluruhan unit analisis yang diperhitungkan sebagai populasi dalam penelitian ini adalah rumah tangga yang memiliki pekerjaan sebagai pengerajin tenunan tradisional. Data dikumpulkan dengan teknik wawancara, observasi dan pencatatan dokumen, selanjutnya dianalisis secara deskriptif kualitatif. Hasil penelitian menunjukkan : (1) secara hitungan kasar tingkat produktivitas yang dihasilkan dari pekerjaan menenun dapat dikatakan masih relatif rendah, (2) Tingkat Produktivitas Kerja (TPK) kelompok pengerajin wanita di Desa Jineng Dalem adalah sebesar $63.3 \%$. Kontrtibusi yang diberikan pengerajin wanita di desa Jineng Dalem terhadap perekonomian keluarga bervariasi dari $16.7 \%$ sampai $75 \%$. Sebagai usaha kerajinan tradisional, pekerjaan menenun merupakan pekerjaan yang didapat secara turun temurun dari generasi ke generasi dengan sistem kekeluargaan, tanpa ada sistem pendidikan atau lembaga pelatihan yang jelas.
\end{abstract}

Kata-kata kunci : produktivitas, tingkat partisipasi kerja, pengerajin

\begin{abstract}
This study aims to find out and learn about the : (1) productivity of women in traditional weaving craftsmen in Jineng Dalem Village Buleleng Regency of Bali, (2) the level of labor force participation, the women weave traditional craftsmen in Jineng Dalem village Buleleng regency of Bali, (3) contribution to the family economy by the women weave traditional craftsmen in Jineng Dalem Regency Buleleng Regency of Bali, (4) regeneration system conducted in the continuing effort of traditional weaving in Jineng Dalem village Buleleng regency of Bali.
\end{abstract}

Produktivitas Kerja Dan Tingkat Partisipasi.....(I Gede Sudirtha, Putu Agus Mayuni) 
Subek of this study were womens weaving traditional craftsmen in the village of Dalem Jineng Buleleng Regency. Respondents in this study were : the womens who worked as craftsmen weaving (excluding those schools). Thus the overall calculated as the unit of analysis in this study is a population of households with traditional weaving work as craftsmen. Data were collected by interview, observation and recording of documents, analyzed by descriptive qualitative. The results showed : (1) the raw count rate of productivity resulting from the work of weaving can be said is still relatively low, (2) work productivity level women's group craftsmen in the Jineng Dalem village amounted to $63.3 \%$. Kontrtibution given from women craftsmen in Jineng Dalem village for the family economy varies from $16.7 \%$ to $75 \%$. As a traditional craft businesses, job weaving a job obtained from generation to generation with the family system, without any system of education or training institutions that clear.

Keywords : productivity, labor force participation rate, craftsmen

\section{PENDAHULUAN}

Meningkatnya partisipasi wanita dalam kegiatan ekonomi dapat dipandang sebagai pertanda peralihan status wanita sebagai pekerja keluarga dalam kegiatan rumah tangga (domestik) atau kegiatan pertanian menjadi pekerja upahan yang merupakan status sebagai penerima upah mandiri. Hal ini dapat dilihat sebagai tanda dari semakin pentingnya peranan sektor nonpertanian dalam penyerapan tenaga kerja, khususnya wanita. Salah satu bagian dari pekerjaan di sektor nonpertanian yang banyak menyerap tenaga kerja wanita adalah industri kecil. Seperti yang diungkapkan oleh Saleh (1996) dan Susilastuti, dkk (1994) unit usaha industri kecil dan rumah tangga merupakan 99,5\% dari keseluruhan unit industri yang ada di Indonesia, sedangkan penyerapan tenaga kerjanya adalah 86,6\% dari keseluruhan tenaga kerja yang diserap di sektor industri . Hal ini berarti betapa besarnya penyerapan tenaga kerja wanita di sektor industri kecil.

Desa Jineng Dalem sebagai salah satu desa yang ada di Kabupaten Buleleng merupakan salah satu desa sentra industri , khususnya industri dalam hal kerajinan tenunan tradisional yang berkembang secara turun temurun. Sejak awal perkembangannya, kerajinan tenunan tersebut dikerjakan oleh para kaum wanita/ ibu-ibu rumah tangga sebagai pekerjaan sambilan di luar pertanian sebagai mata pencaharian utama di desa tersebut. 
Dalam kenyataannya, sebagai pekerjaan sambilan, kerajinan tenunan yang ada di desa tersebut mengalami pasang surut. Pasang surut ini disebabkan karena pengaruh pasar global di bidang tekstil dan produk tekstil (TPT), salah satunya adalah membanjirnya produk tekstil Cina ke Indonesia. Banyak pengusaha TPT di Indonesia kususnya Bali yang mengalami gangguan akibat membanjirnya TPT Cina masuk ke Indonesia. Dalam harian Bali Post, 7 Maret 2006 disebutkan industri tekstil dan produk tekstil (TPT) Indonesia makin merana, karena di pasar ekspor kalah saing dengan negara-negara lain seperti Cina dan India, hal ini diperparah lagi dengan membanjirnya TPT Cina dan Korea selatan ke Indonesia dan Bali kususnya, sehingga terjadilah persaingan yang tidak seimbang. Lebih lanjut di harian yang sama disebutkan upaya yang harus dilakukan dalam meninbgkatkan kembali gairah TPT di Indonesia kususnya Bali adalah mempertahankan ciri khas. Pelaku industri semestinya mengangkat kembali kelebihan dari industri TPT. Di Bali, misalnya dari dulu Bali memiliki kelebihan terutama di hand made-nya. Kenapa bukan itu yang dikembangkan?. Buktinya baju-baju renda, dan tekstil tradisional lainnya, meskipun volumenya kecil namun hingga kini mampu bertahan, dan setidaknya mampu menghidupi ratusan bahkan ribuan orang yang terlibat di dalamnya.

Dari fenomena yang ada seperti disebutkan di atas, jenis tekstil tradisional seperti tenunan songket dan lainnya yang memiliki ciri khas tradisional Indonesia tetap bertahan. Karena memang secara kenyataan produk tekstil tradisional tetap diminati dan tidak ada duanya di dunia, karena proses perbuatannya, bahan, dan motif dikerjakan secara tradisional dengan teknik tertentu. Setidaknya dengan mempertahankan ciri khas yang kita miliki yang secara nyata dan sejak lama sudah diminati, harus dapat dijadikan keunggulan dalam daya saing dengan produk luar.

Keberadaan para wanita penenun tradisional yang ada di Bali tidak bisa diabaikan keberadaanya. Sudah terbukti secara turun-temurun keberadaan mereka dalam mempertahankan budaya tradisional dari tahun-ke tahun, bahkan dari berabad-abad lamanya dan masih eksis sampai sekarang walaupun diterpa dengan berbagai persoalan. Untuk itu dalam penelitian ini akan mencoba mengangkat berbagai persoalan yang terkait dengan produktivitas dan partisipasi kerja para wanita penenun tradisional, serta sumbangannya terhadap peningkatan 
perekonomian keluarga di komunitas pengerajin yang ada di desa Jineng Dalem Buleleng Bali .

Rumah tangga sebagai suatu unit sosial terkecil, juga sekaligus merupakan suatu unit ekonomi yang berkewajiban memenuhi kebutuhan anggotanya. Disamping itu setiap rumah tangga juga berfungsi memproduksi barang dan jasa , baik yang dapat dipasarkan (marketable), maupun yang tidak dapat dipasarkan (unmarketable). Dalam hal ini, sebagai unit ekonomi, rumah tangga memiliki fungsi ganda, disatu sisi sebagai konsumen, di sisi lain berfungsi sebagai produsen .

Guna menjalankan fungsinya, untuk mempertahankan tingkat subsistensinya dan sekaligus memaksimalkan kepuasannya (utility), rumah tangga akan dihadapkan pada berbagai kendala yang ada, atau berbagai perubahan kondisi social ekonomi sebagai dampak dari adanya pembangunan. Bagi rumah tangga yang kaya, kendala atau perubahan yang terjadi tidak begitu menjadi masalah. Bagi rumah tangga miskin, salah satu upaya yang ditempuh untuk memaksimalkan kepuasannya adalah dengan memanfaatkan tenaga kerja yang dimiliki secara optimal. Dalam hubungan inilah kemudian muncul konsep Strategi Rumah Tangga (Household Adaption Strategi), yang kemudian berkembang hingga ke Indonesia (Firman, 1990).

Keterlibatan wanita dalam kegiatan ekonomi sebagai pekerja di negaranegara sedang berkembang, lebih dapat dipandang sebagai suatu strategi rumah tangga, dalam usahanya untuk tetap dapat mempertahankan kelangsungan hidup rumah tangganya. Dalam hal ini, laki-laki dianggap sebagai pencari nafkah utama. Minimnya pendapatan laki-laki menyebabkan anggota rumah tangga lainnya ikut terlibat dalam kegiatan ekonomi sebagai pekerja. Dengan demikian jelas terlihat bahwa keterlibatan wanita dalam kegiatan ekonomi sebagai pencari nafkah dapat dijelaskan dengan landasan konsep Household Adaption Strategi .

Sementara di Bali, keterlibatan wanita dalam kegiatan ekonomi sebagai pekerja dipengaruhi oleh nilai-nilai budaya lokal. Misalnya penelitian Sutjipta dan Sudarta (1985), Yogi Swara (1985), Arini (1986), menunjukkan nilai-nilai agama Hindu dan status social wanita berpengaruh terhadap pola kerja. Penelitian senada yang dilakukan oleh Parmiti (1990) tentang mobilitas kerja wanita Bali, mengemukakan wanita Bali bekerja berdasarkan atas falsafah agama Hindu yaitu Tri 
Hita Karana yang artinya tiga penyebab kebaikan, yakni : (1) keserasian hubungan antara manusia dengan Tuhan, (2) manusia dengan manusia,(3) manusia dengan lingkungan. Dengan demikian agar terwujud kehidupan selaras, serasi, dan seimbang dalam kehidupan manusia, maka manusia harus melakukan kerja, karena dengan bekerja mereka bisa melakukan yadnya, sehingga terpenuhi kebutuhan jasmani dan rohani sesuai dengan falsafah Tri Hita Karana tersebut.

Secara fililosofis, produktivitas mengandung pandangan hidup dan sikap mental yang selalu berusaha untuk meningkatkan mutu kehidupan ( Payaman J.S., 1985 : 30). Dalam pandangan ini, keadaan hari ini harus lebih baik dari hari kemarin, dan mutu kehidupan besok harus lebih baik dari hari ini. Pandangan hidup dan sikap mental yang demikian akan mendorong manusia untuk tidak cepat merasa puas. Sehingga dengan demikian akan terus diusahakan pengembangan diri dan meningkatkan kemampuan kerja

Pertumbuhan penduduk akan sangat mempengaruhi pertumbuhan angkatan kerja. Semakin besar jumlah penduduk usia kerja, maka secara otomatis jumlah angkatan kerja akan bertambah. Semakin tinggi TPK semakin baik, karena itu berarti partisipasi angkatan kerja semakin meningkat. Tingkat partisipasi kerja (TPK) atau Labour Force Participation Rate (LFPR) suatu kelompok penduduk tertentu adalah perbandingan antara jumlah angkatan kerja dengan penduduk dalam usia kerja dalam kelompok yang sama. TPK dapat dinyatakan untuk seluruh penduduk dalam usia kerja dan dapat pula dinyatakan untuk suatu kelompok penduiduk tertentu seperti kelompok laki-laki, perempuan di kota, kelompok umur, dll (Payaman J.S., $1985: 36$ ).

Bali merupakan salah satu daerah yang dikenal dengan kain tenunanya, baik dalam bentuk tenunan dengan desain ikat pakan yang disebut kain endek, songket, prada, pelangi, maupun yang menonjol yaitu kain gringsing dobel ikat. Dalam kebudayaan Bali, kain tenunan ini penting artinya sebagai unsur pakaian yang harus disiapkan oleh setiap individu didalam melakukan kegiatan tertentu, semisal kegiatan adat dan keagamaan.

Suwati Kartiwa (1989 : 67) mengumukakann, penggunaan macam-macam kain tenunan dalam adat Bali (selanjutnya dikenal dengan tata busana adat Bali) 
lebih banyak di pengaruhi oleh unsur-unsur dalam agama Hindu- Bali. Dalam hubungan penggunaan kain tenun untuk menghormati Tuhan, leluhur, dan kain tenunan tertentu dipakai untuk menolak malapetaka yang ditimbulkan oleh roh-roh jahat. Kewajiban untuk mengenakan kain tenunan tertentu tersebut baik untuk setiap individu maupun seluruh komuniti yang terlibat melakukan kegiatan upacara tertentu.

Umumnya pekerjaan menenun ini dilakukan oleh para wanita khusunya ibuibu rumah tangga. Pada mulanya tenunan songket yang merukapan tenunan tradisional dibuat khusus untuk konsumsi sendiri dalam artian dibuat untuk keperluan diri sendiri maupun keluarga. Namun seiring dengan perkembangan jaman, tenunan tradisional mengalami perkembangan dari segi pemanfatannya sehingga tenunan tradisional dijadikan salah satu komuditi usaha yang dapat menciptakan lapangan kerja baru. Hal tersebut nampaknya menyebabkan terjadinya perluasan kesempatan kerja terutama bagi kaum wanita, khususnya ibu-ibu rumah tangga banyak yang terlibat sebagai pekerja maupun pekerja sambilan sebagai penenun.

Keberadaan tenunan atau kain tradisional Bali merupakan suatu kebutuhan yang tidak dapat dipisahkan dari bidang sosial, adat dan kegiatan keagamaan (Hindu). Sejalan dengan perkembangan jaman, tenunan tradisional mengalami perkembangan dari segi pemanfatannya sehingga tenunan tradisional dijadikan salah satu komuditi usaha yang dapat menciptakan lapangan kerja baru. Hal tersebut nampaknya menyebabkan terjadinya perluasan kesempatan kerja terutama bagi kaum wanita, khususnya ibu-ibu rumah tangga banyak yang terlibat sebagai pekerja maupun pekerja sambilan sebagai penenun.

Sebagai suatu strategi kelangsungan hidup rumah tangga, keikutsertaan wanita/istri dalam mencari nafkah sangat membantu menambah pendapatan rumah tangga. Dengan demikian, para wanita tidak hanya bertugas mengurus rumah tangga (domestic role )yang tidak menghasilkan uang, namun telah mampu ikut mencarai nafkah sebagai peranan publik ( occupational role).

Memperhatikan permasalahan berkaitan dengan pekerja wanita seperti yang telah dikemukakan dalam pendahuluan, dan semakin terlibatnya wanita sebagai 
pekerja di Desa Jineng Dalem, maka ada beberapa pertanyaan yang ingin dicarikan jawabannya dalam penelitian yang dapat dirumuskan seperti berikut : (1) bagaimana produktivitas kerja para wanita pengerajin tenunan tradisional di Desa Jineng Dalem Kabupaten Buleleng Bali? (2) bagaimana tingkat partisipasi kerja (TPK) para wanita pengerajin tenunan traditional di Desa Jineng Dalem Kabupaten Buleleng Bali? (3) berapa besar kontribusi terhadap perekonomian keluarga oleh para wanita pengerajin tenunan tradisional di Desa Jineng Dalem Kabupaten Buleleng Bali (4) bagaimana sistem regenerasi yang dilakukan dalam meneruskan usaha tenunan tradisional di Desa Jineng Dalem Kabupaten Buleleng Bali?

Tujuan penelitian ini adalah sebagai berikut : (1) mengetahui dan mengkaji produktivitas kerja para wanita pengerajin tenunan tradisional di Desa Jineng Dalem Kabupaten Buleleng Bali, (2) mengetahui dan mengkaji tingkat partisipasi kerja (TPK) para wanita pengerajin tenunan traditional di Desa Jineng Dalem Kabupaten Buleleng Bali, (3) mengetahui dan mengkaji besarnya kontribusi terhadap perekonomian keluarga oleh para wanita pengerajin tenunan tradisional di Desa Jineng Dalem Kabupaten Buleleng Bali, dan (4) mengkaji sistem regenerasi yang dilakukan dalam meneruskan usaha tenunan tradisional di Desa Jineng Dalem Kabupaten Buleleng Bali. Sedangkan manfaat yang diharapkan dari penelitian ini adalah untuk memperdalam pemahaman tentang keberadaan para penenun tradisional yang ada di Bali tidak bisa diabaikan keberadaanya. Sejalan dengan perkembangan jaman, tenunan tradisional mengalami perkembangan dari segi pemanfatannya sehingga tenunan tradisional dijadikan salah satu komuditi usaha yang dapat menciptakan lapangan kerja baru. Hal tersebut nampaknya menyebabkan terjadinya perluasan kesempatan kerja terutama bagi kaum wanita, khususnya ibu-ibu rumah tangga banyak yang terlibat sebagai pekerja maupun pekerja sambilan sebagai penenun.

\section{METODE PENELITIAN}

Penelitian dilakukan di Desa Jineng Dalem, Kecamatan Buleleng Kabupaten Buleleng Bali, sebagai sentra pengerajin tenunan tradisional. Responden dalam penelitian ini adalah : para wanita yang bekerja sebagai pengerajin tenun (tidak 
termasuk yang sedang sekolah). Dengan demikian keseluruhan unit analisis yang diperhitungkan sebagai populasi dalam penelitian ini adalah rumah tangga yang memiliki pekerjaan sebagai pengerajin tenunan tradisional.

Data dikumpulkan dengan teknik wawancara, observasi dan pencatatan dokumen. Data yang diperoleh dalam penelitian ini dianalisis secara deskriptif kualitatif yaitu suatu analisis data yang dilakukan dengan jalan menyusun secara sistematis informasi-informasi yang diperoleh secara mendalam mengenai suatu objek yang diteliti, sehingga diperoleh kesimpulan umum.

\section{HASIL PENELITIAN DAN PEMBAHASAN}

\subsection{Hasil Penelitian}

Sebagai wadah komunikasi dalam mengembangkan usaha para pengerajin di Desa Jineng Dalem para pengerajin membentuk kelompok usaha bersama yang terdiri dari 6 kelompok. Masing masing kelompok terdiri dari 9 sampai 14 orang pengerajin. Kelompok tersebut terdiri darti kelompok Sinta, Kelompok Kunti, Kelompok Supraba, Kelompok Satyawati, Kelompok Srikandi, dan Kelompok Kunti. Usia rata-rata pengerajin berkisar antara 24 sampai 62 tahun, dan ada salah satu pengerajin sampai 72 tahun. Rata-rata usia ini masih dalam usia produktif. Sedangkan rata-rata jam kerja perhari berkisar antara 6 sampai 8 jam, dan ada yang sampai menambah jam lembur pada saat ada pesanan lebih. Kadang-kadang juga ada yang meninggalkan pekerjaan menenun untuk sementara untuk mencari napkah untuk memenuhi keperluan sehari-hari untuk sementara atau musiman seperti melakukakan pekerjaan memotong/ memanen padi saat musim panen.

Jenis tenunan yang dihasilkan dari pengerajin dapat berupa : kain/ kamben dengan motif penuh dan motif pinggiran, udeng atau destar, selendang, dll. Untuk kain kamben dengan motif penuh dikerjakan sampai 30 hari. Sedangkan kain kamben dengan motif pinggiran dikerjakan sampai 14 hari. Lamanya waktu pengerjaan disebabkan karena tenunan tradisional tersebut termasuk tenunan yang sepenuhnya dikerjakan dengan sentuhan tangan dengan bantuan alat tradisional berupa cag-cag. Ukuran kain juga mempengaruhi lama waktu pengerjaan. Untuk 
pembuatan selendang, stagen, dan destar membutuhkan waktu pengerjaan sampai 4 hari.

3.1.1. Produktivitas kerja para wanita pengerajin tenunan tradisional di Desa Jineng Dalem Kabupaten Buleleng Bali

Produktivitas kerja para pengerajin tenunan di Desa Jineng Dalem digambarkan secara umum para pengerajin memperoleh hasil dari proses produksi berkisar antara 1 lembar kain tenunan kamben motif penuh dalam sebulan 1 setengah lembar kain tenunan dengan motif pinggiran dalam sebulan, dan antara 6 sampai 7 lembar berupa selendang, atau berupa destar, atau berupa stagen, antara 3 lembar. Jika di hitung dalam nilai uang maka dapat dihitung antara Rp. 150.000 sampai Rp. 500.000,-.

Dengan demikian secara hitungan kasar tingkat produktivitas yang dihasilkan dari pekerjaan menenun dapat dikatakan masih relatif rendah. Oleh sebab itu untuk meningkatkan produktivitas sebagai angkatan kerja dalam rumah tangga, para wanita pengerajin di desa Jineng Dalem mencari pekerjaan lain di sela-sela waktu menenun. Pekerjaan yang diambil selain menenun dari 62 orang pengerajin di Desa Jineng Dalem dapat dirinci seperti : pekerjaan berdagang sebanyak 15 orang (24.2\%), sebagai petani dan pemanen padi sebanyak 14 orang (22.5\%), sebagai penjahit pakaian dan pembuat motif sebanyak 4 orang (6.5\%), sebagai pegawai 1 orang (1.6\%), dan sisanya 27 orang $(43.55 \%)$ tidak memiliki pekerjaan lain, dalam artian hanya sebagai ibu rumah tangga.

3.1.2. Tingkat partisipasi kerja (TPK) para wanita pengerajin tenunan traditional di Desa Jineng Dalem Kabupaten Buleleng Bali

Tingkat partisipasi kerja kelompok wanita pengerajin dalam kelompoknya dapat diperoleh perhitungan sebagai berikut :

TPK kelompok pengerajin wanita $=$ Jumlah angkatan kerja dalam kelompok pengerajin (62 orang) dibagi dengan jumlah tenaga kerja dalam kelompok pengerajin (98 orang) dikalikan $100 \%$. Jadi TPK kelompok pengerajin wanita di Desa Jineng Dalem adalah sebesar 63.3\%. 
3.1.3. Kontribusi para wanita pengerajin tenunan tradisional di Desa Jineng Dalem Kabupaten Buleleng Bali terhadap perekonomian keluarga

Kontribusi atau sumbangan wanita pengerajin tenunan tradisional di desa Jineng Dalem terhadap perekonomian keluarga sangat bervariasi. Keadaan ini sangat dipengaruhi oleh keadaan sosial ekonomi rumah tangganya. Semakin rendah keadaan sosial ekonomi keluarganya maka semakin besar kontribusi yang diberikan pada perekonomian keluarga. Dalam hal ini rendahnya keadaan sosial ekonomi keluarga menyebabkan wanita melibatkan diri sebagai pengerajin tenunan dan pekerjaan laiinnya dalam upaya meningkatkan pendapatan keluarga dalam memenuhi kebutuhan hidupnya.

Dilihat dari jumlah rata-rata penghasilan mereka dari kegiatan sebagai penenun (antara Rp. 150.000,- sampai Rp. 500.000,-) dibandingkan dengan jumlah penghasilan keluarga secara keseluruhan (antara Rp. 200.000,- sampai Rp. 3.000.000,-) maka kontribusinya dapat dihitung antara 16.7\% sampai 75\%. (dihitung dari jumlah pengahsilan rata-rata dari hasil menenun para wanita pengerajin dibagi dengan penghasilan rata-rata keluarga dalam sebulan, kemudian dikalikan 100\%).

3.1.4. Sistem regenerasi yang dilakukan dalam meneruskan usaha tenunan tradisional di Desa Jineng Dalem Kabupaten Buleleng Bali

Sebagai usaha kerajinan tradisional, kerajinan tenunan tradisional di desa Jineng Dalem, pekerjaan menenun merupakan pekerjaan yang didapat secara turun temurun dari generasi ke generasi dengan sistem kekeluargaan, tanpa ada sistem pendidikan atau lembaga pelatihan yang jelas. Menurut penuturan masyarakat pengerajin dikatakan belajar menenun bagi orang-orang yang berada di lingkungan desa Jineng Dalem tidak begitu sulit. Masyarakat Desa Jineng Dalem terutama para wanita dan ibu rumah tangga yang berminat terhadap pekerjaan menenun cukup berlatih dari orang tua atau siapapun dari masyarakat desa Jineng Dalem yang bisa menenun. Proses pelatihan biasanya berawal dari melihat para seniornya pada saat bekerja atau membantu sambil ngobrol. Secara tidak disengaja dengan melihat atau membantu pekerjaan menenun telah memberti pengetahuan dasar bagi mereka. 
Selanjutnya tinggalitu mempraktekkan atau melatih diri secara terus menerus sampai bisa di bawah bimbingan seniornya (orang tua, mertua, atau kerabat).

Dari 62 orang pengerajin di desa Jineng Dalem sebagian besar (55 orang atau $88.7 \%$ ) menyebutkan keterampilan menenun diperoleh dari orang tua atau mertua. Sisanya 7 orang (11.3\%) memperoleh keterampilan menenun dari orang lain (kerabat, tetangga).

Jadi sistem regenerasi para penenun tradisional di desa Jineng Dalem dalam upaya melanjutkan usaha tradisional ini adalah dengan jalan melatih anak-anak atau menantu mereka secara langsung dan bersipat turun temurun. Disamping itu salah satu sekolah dasar (SD Negeri 2 Jineng Dalem) telah memasukkan kegiatan menenun sebagai kurikulum muatan lokal yang wajib diikuti oleh setiap siswa perempuan. Skegiatan belajar dan pelatihan ini difasilitasi dengan membeli alat (cag-cag) dari pengerajin tenun di desa setempat, dan tenaga pengejar atau pelatih difasilitasi oleh pengerajin dari kelompok Kunti yaitu Ketut Karmini.

\subsection{PEMBAHASAN}

Secara umum pengerajin wanita memperoleh hasil dari proses produksi dalam kisaran antara 1 lembar kain tenunan kamben motif penuh dalam sebulan 1 setengah lembar kain tenunan dengan motif pinggiran dalam sebulan, dan antara 6 sampai 7 lembar berupa selendang, atau berupa destar, atau berupa stagen, antara 3 lembar. Jika di hitung dalam nilai uang maka dapat dihitung antara Rp. 150.000 sampai Rp. 500.000,-.

Dengan demikian secara hitungan kasar tingkat produktivitas yang dihasilkan dari pekerjaan menenun dapat dikatakan masih relatif rendah. Oleh sebab itu untuk meningkatkan produktivitas sebagai angkatan kerja dalam rumah tangga, para wanita pengerajin di desa Jineng Dalem mencari pekerjaan lain di sela-sela waktu menenun. Pekerjaan yang diambil selain menenun dari 62 orang pengerajin di Desa Jineng Dalem dapat dirinci seperti : pekerjaan berdagang sebanyak 15 orang (24.2\%), sebagai petani dan pemanen padi sebanyak 14 orang (22.5\%), sebagai penjahit pakaian dan pembuat motif sebanyak 4 orang (6.5\%), sebagai pegawai 1 
orang (1.6\%), dan sisanya 27 orang (43.55\%) tidak memiliki pekerjaan lain, dalam artian hanya sebagai ibu rumah tangga.

Relatif rendahnya produktivitas pengerajin di desa Jineng Dalem merupakan dampak dari beberapa hal seperti ; melemahnya pasar dari kain tenun tradisional yang disebabkan tingginya nilai produksi yang berakibat pada tingginya harga jual kain. Tingginya nilai produksi secara keseluruhan dikarenakan dari harga bahan baku yang cukup tinggi, dan yang paling menentukan adalah proses pembuatan yang relatif panjang dan membutuhkan waktu yang lama dengan sentuhan nilai-nilai tradisional yang tidak dapat tergantikan oleh kain apapun. Produktivitas mereka akan meningkat pada saat pesanan meningkat.

Keadaan seperti yang dialami oleh para pengerajin tenun tradisional di Desa Jineng Dalem ini merupakan pengaruh dari hal-hal yang berkaitan dengan pekerjaan atau proses produksinya seperti manajemen produksi, manajemen biaya, manajemen waktu, sistem dan teknologi yang relatif masih tradisional. Hal ini sesuai dengan pandangan dari Sedarmayanti, 2001 : 56., yang mengatakan produktifitas adalah sikap mental yang mempunyai semangat untuk melakukan peningkatan atau perbaikan. Perwujudan sikap mental dalamdalambagai kegiatan antara lain yang berkaitan dengan diri sendiri, dan yang berkaitan dengan pekerjaan.

Produktivitas dapat ditingkatkan melalui bagaimana menghasilkan atau meningkatkan hasil barang atau jasa setinggi mungkin dengan memanfaatkan sumber daya secara efisien (Paul Mali, dalam Sedarmayanti : 2001). Dengan demikian produktivitas pengerajin di desa Jineng Dalem dapat meningkat jika pesanan meningkat pula. Selama ini produksi kain tenun dibuat berdasarkan pesanan baik perorangan maupun pesanan dari pengepul. Disamping itu produktivitas dapat ditingkatkan karena mereka penuh dengan motivasi untuk berjuang dalam meningkatkan kesejahteraan hidup dengan mencari pekerjaan lain pada saat mereka tidak memperoleh pesanan. Dengan demikian secara sikap mental motivasi tersebut merupakan salah satu indikator untuk meningkatkan produktivitas di samping indikator lain seperti : desiplin, kreatif, inovatif , dinamis dan profesional. hal ini sejalan dengan pandangan John W. Artkinson, (dalam Sedarmayanti : 2001) yang menyatakan motivasi pribadi untuk bertindak adalah hasil interaksi dari kekuatan 
diri sendiri atau kebutuhan, keinginan untuk berhasil, dan nilai insentif yang melekat pada tujuan.

Tingkat Produktivitas Kerja (TPK) kelompok pengerajin wanita di desa Jineng Dalem sebesar 63\% dalam kelompok pengerajin yanmg berjumlah 62 orang. Angka 63\% terbilang cukup tinggi dan berada dalam kisaran di atas 50\%. Tingginya tingkat partisipasi tersebut yang mencerminkan penyediaan tenaga kerja atau jumlah angkatan kerja. Semakin tinggi tingkat partisipasi kerja mencerminkan semakin bertambahnya jumlah atau penyediaan tenaga kerja. Hal ini penyediaan tenaga kerda dalam kaitan ini pada saranya merupakan hasil keputusan seluruh keluarga yang menentukan berapa dan siapa dalam keluarga yang masuk pasar kerja (Payaman1985 : 56).

Kontrtibusi yang diberikan pengerajin wanita di desa Jineng Dalem terhadap perekonomian keluarga bervariasi dari $16.7 \%$ sampai $75 \%$. Keadaan seperti ini menunjukkan demikian pentingnya peran wanita pengerajin dalam menunjang perekonomian keluarga di desa Jineng Dalem, belum lagi kontrtibusi mereka di luar penghasilannya sebagai penenun seperti yang disebutkan pada uraian hasil penelitian sebelumnya, misalnya dari hasil berdagang, buruh tani, menjahit, dll.

Kontribusi atau sumbangan wanita pengerajin tenunan tradisional di desa Jineng Dalem terhadap perekonomian keluarga sangat bervariasi. Jika dikaitkan dengan kontribusi wanita pengerajin di Desa Jineng Dalem terhadap perekonomian keluarga, maka keadaan ini sangat dipengaruhi oleh keadaan sosial ekonomi rumah tangganya. Semakin rendah keadaan sosial ekonomi keluarganya maka semakin besar kontribusi yang diberikan pada perekonomian keluarga. Kontribusi ini dilakukan oleh para wanita pengerajin pada rumah tangga dengan keadaan sosial ekonomi relatif kurang dengan alasan untuk memberikan sumbangan atau meningkatkan kesejahteraan hidup yang lebih tinggi dari keluarganya. Hal ini sejalan dengan hasil penelitian I B Astawa tentang Studi tentang Para Pekerja Wanita dan Pemanfaatannya Di Daerah Wisata Desa Mas Ubud Gianyar, 1998 : 49), yang menunjukkan rendahnya penghasilan kepala rumah tangga menyebabkan para ibu rumah tangga atau anggota kel;uarga yang lain untuk ikut ambil bagian sebagai pekerja dengan demikian hasil atau pendapatan rumah tangga akan semakin besar. 


\section{PENUTUP}

Secara umum pengerajin memperoleh hasil dari proses produksi berkisar antara 1 lembar kain tenunan kamben motif penuh dalam sebulan 1 setengah lembar kain tenunan dengan motif pinggiran dalam sebulan, dan antara 6 sampai 7 lembar berupa selendang, atau berupa destar, atau berupa stagen, antara 3 lembar. Jika di hitung dalam nilai uang maka dapat dihitung antara Rp. 150.000 sampai Rp. 500.000,-. Dengan demikian secara hitungan kasar tingkat produktivitas yang dihasilkan dari pekerjaan menenun dapat dikatakan masih relatif rendah.

Jumlah angkatan kerja dalam kelompok pengerajin tenunan sebanyak 62 orang, sedangkan jumlah tenaga kerja dalam kelompok pengerajin tenunan sebanyak 98 orang. Dengan demikian tingkat partisipasi kerja kelompok wanita pengerajin dalam kelompoknya dapat ditentukan dengan jumlah angkatan kerja dalam kelompok pengerajin (62 orang) dibagi dengan jumlah tenaga kerja dalam kelompok pengerajin (98 orang) dikalikan 100\%. Jadi TPK kelompok pengerajin wanita di Desa Jineng Dalem adalah sebesar 63.3\%.

Kontrtibusi yang diberikan pengerajin wanita di desa Jineng Dalem terhadap perekonomian keluarga bervariasi dari $16.7 \%$ sampai $75 \%$. Keadaan seperti ini menunjukkan demikian pentingnya peran wanita pengerajin dalam menunjang perekonomian keluarga di desa Jineng Dalem, belum lagi kontrtibusi mereka di luar penghasilannya sebagai penenun seperti yang disebutkan pada uraian hasil penelitian sebelumnya, misalnya dari hasil berdagang, buruh tani, menjahit, dll.

Sebagai usaha kerajinan tradisional, pekerjaan menenun merupakan pekerjaan yang didapat secara turun temurun dari generasi ke generasi dengan sistem kekeluargaan, tanpa ada sistem pendidikan atau lembaga pelatihan yang jelas. Dari 62 orang pengerajin di desa Jineng Dalem sebagian besar (55 orang atau $88.7 \%$ ) menyebutkan keterampilan menenun diperoleh dari orang tua atau mertua. Sisanya 7 orang $(11.3 \%)$ memperoleh keterampilan menenu dari orang lain (kerabat, tetangga). Jadi sistem regenerasi para penenun tradisional di desa Jineng Dalem dalam upaya melanjutkan usaha tradisional ini adalah dengan jalan melatih anakanak atau menantu pengerajin melalui secara langsung dan berlangsung turun temuru. Disamping itu salah satu sekolah dasar (SD Negeri 2 Jineng Dalem) telah 
memasukkan kegiatan menenun sebagai kurikulum muatan lokal yang wajib diikuti oleh setiap siswa perempuan..

\section{DAFTAR PUSTAKA}

Astawa. I. B. 1998. Laporan Penelitian. Studi tentang Para Pekerja Wanita dan Pemanfaatannya Di Daerah Wisata Desa Mas Ubud Gianyar.

Bali Post. Selasa. \& Maret 2006. Pertahankan Ciri Khas, Pemerintah Mesti Serius Garap Industri Garmen.

Dinas Kebudayan Propensi Daerah TK I Bali , 1994. Tata Busana Adat Bali .

Effendi, Tadjuddin Noer. 1995. Sumber Daya Manusia Peluang Kerja dan Kemiskinan. Yogyakarta : PT. Tiara Wacana

Firman, Tommy.1990. Strategi Alokasi Kerja Pada Rumah Tangga . Dalam Prisma 3/III hal 76-91

Gandarsih, Mulyowati RS. 1986. Wanita Jawa dan Kemajuan Jaman. Buletin Antropologi Volume II

Hamalik, Oemar. 2001. Pengembangan Sumber Daya Manusia Manajemen Pelatihan Ketenagakerjaan Pendekatan Terpadu.Jakarta: PT Bumi Akasara

Kartiwa, Suwati. 1989. Kain Songket Indonesia. Jakarta : Djambatan

Payaman, J.S., 1985. Pengantar Ekonomi Sumber Daya Manusia.

Saleh, Harry Heriawan. 2005. Persaingan Tenaga Kerja Dalam Era Globalisasi ( Antara Perdagangan dan Migrasi) . Jakarta : Pustaka Sinar Harapan

Sajogyo, Pudjiwati. 1983. Peranan Wanita Dalam Perkembangan Masyarakat Desa. Jakarta : C.V. Radjawali.

Sedarmayanti, 2001. Sumber Daya Manusia Dan Produktivitas Kerja. Bandung : Mandar Maju.

Subri, Mulyadi, 2003. Ekonomi Sumber Daya Manusia. Jakarta : PT RajaGrafindo Persada. 
JPTK, UNDIKSHA, Vol. 9, No. 1, Januari 2012 : 1 - 16 